\title{
Analisis kadar air biobriket dari limbah baglog jamur tiram dengan penambahan kotoran sapi
}

\author{
1"Baiq Mirawati, ${ }^{2}$ Ismail Effendi, ${ }^{3}$ Achmad Muslihin
}

\begin{abstract}
Abstrak: Tujuan dari penelitian ini adalah untuk mengetahui pengaruh penambahan kotoran sapi terhadap kadar air beriket limbah baglog jamur tiram. Jenis penelitian ini adalah Eksperimen Murni. Rancangan penelitian yang digunakan adalah Rancangan Acak Lengkap (RAL) dan analisis data yang digunakan yaitu ANOVA (Analisis of variance) pada taraf signifikan 5\% dan diuji lanjut menggunakan DMRT (Duncan's Multiple Range Test), dengan 5 perlakuan dan 4 ulangan. Kadar air yang diperoleh dari penelitian ini berkisar antara 2,73\%-5,55\%. Keseluruhan biobriket yang dihasilkan telah sesuai dengan SNI dimana kadar air pada biobriket menurut SNI (SNI 01-6235-2000) yaitu $\leq 8 \%$. Berdasarkan hasil penelitian menunjukkan bahwa kadar air tidak berpengaruh pada pembuatan biobriket dengan menggunakan limbah baglog jamur tiram $(0,05>0,05)$.
\end{abstract}

Kata kunci: Kadar air, Limbah baglog jamur, Biobriket

\section{The Analysis Of Biobriquette Moisture Content From Oyster Mushroom Baglog Waste With The Addition Of Cow Dung}

\begin{abstract}
The purpose of this study was to determine the effect of adding cow dung on the water content of oyster mushroom baglog waste. This type of research is pure experiment. The research design used was a completely randomized design (CRD) and the data analysis used was ANOVA (Analysis of variance) at a significant level of 5\% and further tested using DMRT (Duncan's Multiple Range Test), with 5 treatments and 4 replications. The water content obtained from this study ranged from $2.73 \%-5.55 \%$. The entire biobriquette produced is in accordance with SNI where the water content in the biobriquette according to SNI (SNI 01-6235-2000) is $\leq 8 \%$. The results showed that the water content had no effect on making biobriquettes using oyster mushroom baglog waste (0.50> $0.05)$.
\end{abstract}

Keywords: Moisture content, Mushroom baglog waste, Biobriquette

\section{PENDAHULUAN}

Komoditi pertanian yang mengalami ketidakseimbangan antara permintaan dan penawarannya salah satunya adalah jamur tiram putih, karena tingginya permintaan konsumen akan jamur tiram segar di pasar tidak diiringi oleh peningkatan produksi jamur tiram putih di dalam negeri (Rahmawati, 2012). Pembudidayaan jamur tiram merupakan salah satu usaha peningkatan ekonomi dan pangan yang sangat marak berkembang di masyarakat belakangan ini khususnya di Pulau Lombok, budidaya jamur tiram merupakan komoditi yang mempunyai prospek sangat baik untuk dikembangkan sebab masyarakat sudah mulai mengerti nilai gizi jamur tiram putih ataupun coklat, sehingga banyak masyarakat yang membudidayakan jamur tiram.

Dengan semakin berkembangnya pembudidaya jamur tiram maka diikuti dengan peningkatan limbah baglog jamur tiram yang semakin tinggi sedangkan pengolahan limbahnya belum maksimal dan berimbas kesehatan lingkungan masyarakat. Baglog adalah media tanam jamur yang siap panen. Baglog yaitu media jamur kayu yang terdiri dari serbuk gergaji, tepung tapioka, bekatul/dedak dan kapur. Baglog yang dimaksud sudah terinokulasi (diberi) bibit sehingga anda tidak perlu repot meracik media, sterilisasi dan menanam bibitnya. Baglog telah penuh ditutupi miselium/bibit jamur, ketika plastik baglog dibuka atau dilubangi, jamur akan tumbuh, selanjutnya tinggal merawatnya, 
dan menanti saatnya panen. (Piryadi, 2015). Pada umumnya limbah baglog jamur tiram belum dimanfaatkan secara maksimal. Limbah baglog jamur tiram memiliki komposisi yaitu terdiri dari $80 \%$ serbuk gergaji, $10 \%$ dedak padi, $1,8 \%$ gipsum dan $0,4 \%$ TS. Dari jumlah komposisi tersebut serbuk gergaji dan dedak padi yang paling banyak komposisinya dimana kedua komponen itu memiliki kandungan superkarbon yang dapat dijadikan bahan baku pembuatan bahan bakar alternatif biobriket.

Pengembangan alternatif bahan bakar terus dilakukan, selain memanfaatkan limbah baglok jamur, bahan bakar alternatif lainnya juga dapat dihasilkan dari kotoran sapi. Permasalahan daur ulang kotoran sapi juga merupakan masalah yang harus diselesaikan. Metode penanganan kotoran sapi umumnya masih belum efektif. Penumpukan volume kotoran sapi juga dianggap sebagai masalah baru karena antara pemanfaatan dengan produksi kotoran sapi yang tidak seimbang membuat volume kotoran sapi menjadi semakin tidak terkendali. Kotoran sapi menghasilkan kalor sekitar $4000 \mathrm{kal} / \mathrm{g}$ dan gas metan $\left(\mathrm{CH}_{4}\right)$ yang cukup tinggi. Oleh karena itu dengan mengubah kotoran sapi menjadi biobriket, maka akan meningkatkan nilai ekonomis bahan tersebut. Pada penelitian ini, limbah jamur tiram putih dipilih sebagai bahan biomassa dengan campuran kotoran sapi dengan perbandingan tertentu, yang kemudian dibuat menjadi biobriket

Bioriket adalah bahan bakar padat yang dapat digunakan sebagai sumber energi alternatif yang mempunyai bentuk tertentu. Kandungan air pada pembriketan antara (1020)\% berat. Ukuran biobriket bervariasi dari (20-100) gram. Pembriketan bertujuan untuk memperoleh suatu bahan bakar yang berkualitas yang dapat digunakan untuk semua sektor sebagai sumber energi. Biobriket ini bisa dijadikan energi pengganti arang untuk bahan bakar, dari observasi yang telah dilakukan dalam proses pengukusan atau sterilisasi baglog jamur tiram masyarakat masih menggunakan gas LPG dan kayu bakar untuk mengukus baglog tersebut yang membutuhkan biaya lebih. Untuk meminimalisir biaya pengukusan menggunakan gas LPG serta kayu bakar perlunya sentuhan untuk memanfaatkan limbah baglog jamur tiram agar dapat dijadikan bahan bakar alternatif, terutama membantu petani jamur tiram dalam proses sterilisasi jamurnya yang pembakarannya masih menggunakan LPG atau kayu bakar. Tujuan dari penelitian ini adalah untuk mengetahui kadar air dari pembuatan biobriket yang berbahan baju limbah baglog jamur tiram serta penambahan kotoran sapi.

\section{METODE}

Penelitian ini merupakan penelitian eksperimen yang dilakukan di Laboratorium Kimia Fakultas PMIPA IKIP Mataram. Alat yang digunakan yaitu: Timbangan, paku, drum, ayakan, palu, toples, gelas kimia $25 \mathrm{ml}$, kompor, pengaduk, paralon, thermometer, handphone, lembar pengamatan. Bahan yang digunakan yaitu: adalah tepung tapioka, kotoran sapi, air sebagai bahan pelarut dan, limbah baglog jamur tiram.

Pembuatan biobriket dari limbah baglog jamur tiram diawali dengan pengumpulan bahan baku berupa limbah baglog jamur dan kotoran sapi yang selanjutnya dibersihkan dari material-material tidak berguna. Proses pengeringan limbah baglog jamur dibawah sinar matahari sampai kelihatan kering selama 2-3 hari dan proses pengambilan kotoran sapi dilakukan dalam satu kali pengambilan dalam jumlah banyak, hal ini dilakukan untuk menghindari heterogenitas kotoran sapi yang digunakan dalam penelitian serta proses pengeringan kotoran sapi dilakukan dibawah sinar matahari selama 2-3 hari, setelah cukup kering kotoran sapi kemudian diayak. Limbah baglog jamur tiram yang sudah dikeringkan kemudian disangrai serta limbah cangkang kemiri yang sudah dikeringkan kemudian dimasukkan ke dalam drum sebanyak $2 \mathrm{~kg}$ dan dibakar sehingga menjadi arang. Bahan yang telah disaring lalu dicampur dengan 1 kontrol dan 4 perlakuan yang selanjutnya dicetak menggunakan cetakan manual. Hasil cetakan dikeringkan didalam oven selama 1 jam dengan suhu $105{ }^{\circ} \mathrm{C}$, tujuannya untuk menurunkan kandungan air pada biobriket, sehingga biobriket cepat menyala.

Kadar air biobriket adalah perbandingan berat air yang terkandung dalam biobriket 
dengan berat kering biobriket tersebut setelah dipanaskan atau dikeringkan. Proses pengeringan kadar air merupakan proses untuk menghilangkan kadar air dalam biobriket. Untuk mengetahui kadar air dari suatu bahan bakar padat dapat dilakukan pengeringan dengan menggunakan sinar matahari dan oven listrik, namun pada penelitian ini pengeringan dilakukan dibawah sinar matahari selama 2-3 hari kemudian dianalisis dengan menggunakan persamaan $[$ Pengeringan Kadar air $=(\mathrm{m} 1-\mathrm{m} 2)$ / $\mathrm{m} 1 \times 100 \%$ ] dengan $\mathrm{m} 1$ = massa awal (gr) dan $\mathrm{m} 2=$ massa setelah dikeringkan (gr)

Penelitian ini menggunakan Rancangan Acak Lengkap (RAL), dengan 5 perlakuan dan 4 ulangan yaitu: (1) $\mathrm{P}_{0}=$ Lck $100 \mathrm{gr}+\mathrm{Bk} 50$ gr + Tt 20 gr; (2) $\mathrm{P}_{1}=$ Lbj 100 gr + Ks 25 gr + Tt 20 gr; (3) $\mathrm{P}_{2}=\mathrm{Lbj} 100 \mathrm{gr}+\mathrm{Ks} 20 \mathrm{gr}+\mathrm{Tt}$ 20 gr; (4) $\mathrm{P}_{3}=\mathrm{Lbj} 100 \mathrm{gr}+\mathrm{Ks} 15 \mathrm{gr}+\mathrm{Tt} 20$ gr; dan (5) $\mathrm{P}_{4}=\mathrm{Lbj} 100 \mathrm{gr}+\mathrm{Ks} 10 \mathrm{gr}+\mathrm{Tt} 20$ gr, di mana Lck: Limbah cangkang kemiri; Lbj: Limbah Baglog jamur; Bk: Batok kelapa; Ks: Kotoran sapi; dan Tt: Tepung tapioca.

Populasi penelitian ini adalah semua limbah baglog jamur tiram yang berada di salah satu kumbung jamur Desa Merembu Kecamatan Labuapi Kabupaten Lombok Barat. Sampel dalam penelitian ini adalah $3 \mathrm{~kg}$ Limbah baglog jamur tiram.

Data penelitian dikumpulkan menggunakan teknik observasi dan dokumentasi berupa catatan-catatan sesuai keaadan riil yang ditemukan selama penelitian. Data penelitian selanjutnya dianalisis menggunakan Analisis of varian (ANOVA) dengan taraf signifikan 5\% dan diuji lanjut menggunakan DMRT (Duncan's Multiple Range Test) dengan program SPSS 16 for windows.

\section{HASIL PENELITIAN DAN PEMBAHASAN}

Pengamatan parameter kadar air dilakukan 1 hari setelah pengovenan. Untuk memperjelas hal tersebut dapat dilihat pada Gambar 1.

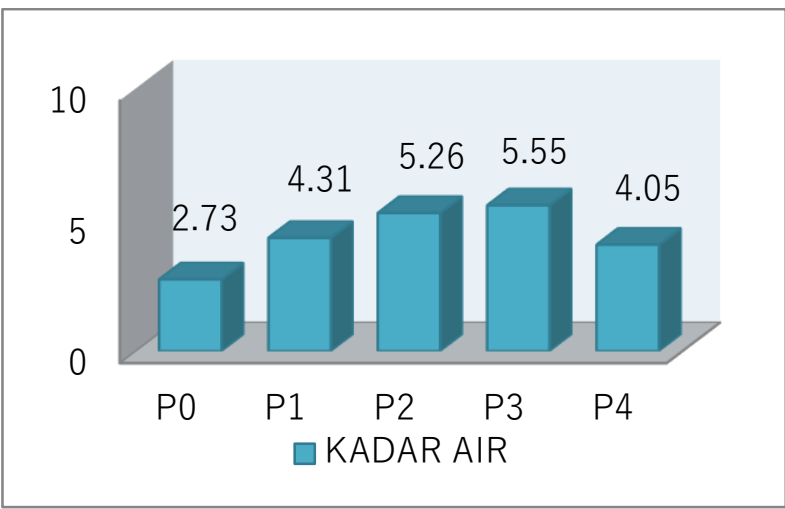

Gambar 1. Grafik kadar air

Gambar 1 menunjukkan bahwa pada perlakuan $\mathrm{P}_{0}$ diperoleh kadar air yang paling rendah yaitu 2.73, sedangkan pada perlakuan $\mathrm{P}_{3}$ menunjukkan kadar air yang paling tinggi yaitu sebesar 5.55. Berdasarkan anaisis statistik menggunakan metode one way ANOVA (analisis varian satu arah) dapat dilihat hasil analisis pada Tabel 1 .

Tabel 1. Hasil uji statistik pengaruh kotoran sapi terhadap kadar air biobriket

\begin{tabular}{|l|l|l|l|l|l|}
\hline & Sum of Squares & Df & Mean Square & F & Sig. \\
\hline Between Groups & 19.864 & 4 & 4.966 & 3.062 & .050 \\
\hline Within Groups & 24.325 & 15 & 1.622 & & \\
\hline Total & 44.190 & 19 & & & \\
\hline
\end{tabular}

Berdasarkan hasil analisis statistik menggunakan metode one way ANOVA pada Tabel 1 diketahui bahwa nilai signifikansi sama besar dari $0,05(0,05=0,05)$ maka H0 diterima, maka dapat disimpulkan bahwa tidak ada pengaruh penambahan kotoran sapi terhadap kadar air biobriket Berdasarkan hasil pengamatan untuk mengetahui kualitas biobriket dilakukan pengujian analisis kadar air yang dilakukan di Laboratorium Kimia FPMIPA IKIP Mataram dengan hasil penelitian menunjukkan bahwa kadar air dari ke-5 perlakuan dengan 4 kali ulangan sesuai dengan SNI, dengan rata-rata kadar 4,31\%, P2 sebesar 5,26\%, P3 sebesar 5,55\%, dan P4 sebesar 4,05\%

Analisis kadar air digunakan untuk mengetahui kadar air biobriket yang telah dikeringkan. Biobriket yang telah disimpan dan dikeringkan dengan menggunakan oven pada suhu $105^{\circ} \mathrm{C}$ selama satu jam berdasarkan metode yang dijelaskan pada metode penelitian. Air menguap pada suhu $100^{\circ} \mathrm{C}$ sehingga pada suhu $105^{\circ} \mathrm{C}$ selama satu jam seluruh air yang ada dalam biobriket akan teruapkan. 
Kadar air sangat mempengaruhi kualitas biobriket yang dihasilkan, semakin rendah kadar air maka nilai kalor dan daya pembakaran akan semakin tinggi dan sebaliknya semakin tinggi kadar air maka nilai kalor dan daya pembakaran akan semakin rendah.

Penentuan kadar air dilakukan untuk mengetahui sifat higroskofis biobriket hasil penelitian. Kadar air yang diperoleh dari penelitian ini berkisar antara 2,73\%-5,55\%. Keseluruhan biobriket yang dihasilkan telah sesuai dengan SNI dimana kadar air pada biobriket menurut SNI (SNI 01-6235-2000) yaitu $\leq 8 \%$.

Pada Gambar 1 terlihat pula bahwa nilai kadar air biobriket terendah sebesar 2,73\% terdapat pada pada komposisi cangkang kemiri 100 gram dan 50 gram batok kelapa, dan nilai kadar air biobriket yang sedang sebesar 4,05\% terdapat pada komposisi limbah baglog jamur tiram 100 gram dan kotoran sapi 10 gram, sementara nilai kadar air biobriket tertinggi sebesar 5,55\% terdapat pada komposisi limbah baglog jamur tiram 100 gram dan kotoran sapi 15 gram.

Kadar air yang tinggi pada komposisi limbah baglog jamur tiram 100 gram dan kotoran sapi 15 gram, jenis perekat dan persentase perekat memberi pengaruh terhadap kadar air yang terkandung dalam biobriket, hal ini disebabkan karena jumlah pori-pori masih cukup banyak sehingga mampu menyerap air. Kadar air yang tinggi akan menyebabkan menurunnya nilai kalor dan efisiensi pembakaran.

Menurut Pancapalaga dalam Santosa, dkk. (2010), tingginya kadar air pada serbuk kotoran sapi karena serbuk kotoran sapi memiliki jumlah pori-pori yang banyak dan masih mengandung komponen-komponen kimia seperti selulosa, lignin, dan hemiselulosa. Nilai kadar air biobriket pada setiap perlakuan masih dibawah nilai SNI yaitu $\leq 8 \%$, hal ini menunjukkan bahwa nilai kadar air biobriket telah memenuhi SNI.

\section{KESIMPULAN}

Berdasarkan hasil penelitian dan pembahasan, maka dapat disimpulkan bahwa penambahan kotoran sapi sebagai campuran pembuatan biobriket tidak memberikan pengaruh yang signifikan pada parameter kadar air biobriket dari limbah baglog jamur tiram.

\section{SARAN}

Penelitian selanjutnya diharapkan untuk mengamati karakteristik biobriket lainnya seperti kadar abu, kerapatan, laju pembakaran biobriket dan kadar karbon untuk memperoleh hasil yang maksimal.

\section{UCAPAN TERIMAKASIH}

Terima kasih kami ucapkan sebesarbesarkan kepada kelompok tani di Desa Merembu atas semua bantuan dan arahannya serta tidak lupa kepada semua tim yang ada di laboratorium Kimia IKIP Mataram atas semua kerjasama yang baik.

\section{DAFTAR PUSTAKA}

Almu M. Afif, S., Padang, Y., A. (2014). Analisa nilai kalor dan laju pembakaran pada briket campuran biji nyamplung (calophyllm inophyllum) dan abu sekam padi. Jurnal Jurusan Teknik Mesin, 4(2).

Irawati, Denny, Naresvara Nircela Pradipta, Johanes Pramana Gentur Sutapa. 2017. Usaha Pemanfaatan Limbah Budi Daya Jamur sebagai Bahan Baku Pembuatan Briket di Kelompok Tani Jamur Sedyo Lestari Desa Argosari, Kecamatan Sedayu, Bantul. Fakulta Kehutanan. Universitas Gadjah Mada. Yogyakarta. Volume. 02 No. 02.

Maryono, Sudding, dan Rahmawati. 2013. Pembuatan dan Analisis Mutu Briket Arang Tempurung Kelapa Ditinjau dari Kadar Kanji. Jurusan Kimia. FMIPA. Universitas Negeri Makasar.

Mushlihah, Siti, Sulfahri, Renia Setyo Utami, Eko Sunarto, dan I.D.A.A Warmadewanthi. 2011. Pengaruh Jenis Bahan Perekat dan Metode Pengeringan Terhadap Kualitas Briket Limbah Baglog Jamur Tiram Putih (Pleurotus ostreatus). ITS : Surabaya.

Purbo, M. Sumedi. 2012. Pelatihan Teknik Budidaya Jamur Edibel bagi 
Masyarakat Pasca Erupsi Merapi. Materi Pelatihan PPM IbM 2012.

Qistina, Idzni, Dede Sukandar, Trilaksono. 2016. Kajian Kualitas Briket Biomassa dari Sekam Padi dan Temprung Kelapa. Program Studi Kimia. Fakultas Sains dan Tekonologi. UIN Syarif Hidayatullah. Jakarta.

Rahmawati, J. 2012. Analisis Kelayakan Pengembangan Usaha Budidaya Jamur Tiram Putih (Kasus: Usaha Jamur Mandiri, Kabupaten Bogor). http://repository.ipb.ac.id/handle/123 456789/56175.

Ratri, Monica Cahyaning., dan Sri Yamtinah. 2012. Pembuatan Briket Arang Dari Limbah Organik Dengan Menggunakan Variasi Komposisi dan Ukuran Bahan. Pendidikan Kimia. FKIP. Universitas Sebelas Maret. Surakarta

Roberto, K. 2003. How-To Hydroponics Fourth Edition. New York: The Futuregarde Press a division of Futuregarden, Inc.

Santosa, Mislaini R., dan Swara Pratiwi Anugrah. 2010. Studi Variasi Komposisi Bahan Penyusunan Briket Dari Kotoran Sapid an Limbah Pertanian. Jurusan Teknik Pertanian, Fakultas Teknologi Pertanian. Universitas Andalas. 